\title{
Peningkatan Kemampuan Pemahaman Siswa SMA Harapan 3 Dengan Metode Context Clues
}

\author{
Juliana \\ Program Studi Pendidikan Bahasa Inggris, Fakultas Ilmu Sosial dan Kependidikan, \\ Universitas Potensi Utama \\ *e-mail: juliana@potensi-utama.ac.id
}

\begin{abstract}
Reading with comprehension can help students to master the topic being taught. However, students have not responded well to reading activity with this comprehension. This is due to the lack of teacher's role in providing effective media and efficient method that help students comprehend reading texts. Even reading with comprehension is an essential factor determining student mastery of taught text. Using context clues is as a solution to enhance students' comprehension. This method can ease students to comprehend reading text applying several stages in form of synonyms, antonyms, examples and explanations to the text. Therefore, the purpose of this community service is to enhance comprehension ability of Harapan 3 Delitua High School students using context clues. The method of implementing activity is lecturing, discussion, and training in comprehending reading texts. The results of activity showed that there was an increase on students' comprehension to English reading texts applying context clues.
\end{abstract}

Keywords: students' comprehension, text, context clues

\begin{abstract}
Abstrak
Kemampuan memahami teks bacaan dapat memudahkan siswa menguasai materi yang diajarkan. Namun, kenyataanya, siswa belum merespon dengan baik kegiatan membaca dengan pemahaman ini. Hal ini disebabkan kurangnya peranan guru dalam memberikan media yang efektif dan metode yang efisien dalam membantu siswa memahami teks bacaan. Padahal membaca dengan pemahaman merupakan faktor penting menentukan penguasaan siswa terhadap materi teks yang diajarkan. Sebagai solusi untuk meningkatkan kemampuan pemahaman siswa adalah dengan menggunakan metode membaca petunjuk konteks (context clues). Metode ini dapat digunakan untuk memudahkan siswa memahami teks bacaan menerapkan beberapa metode petunjuk konteks berupa sinonim, antonim, contoh dan penjelasan. Oleh karena itu, tujuan dari kegiatan pengabdian ini adalah meningkatkan kemampuan pemahaman siswa SMA Harapan 3 Delitua menggunakan metode context clues. Metode pelaksanaan kegiatan ini adalah dengan ceramah, diskusi, dan pelatihan memahami teks bacaan bahasa Inggris menerapkan context clues. Hasil kegiatan menunjukkan bahwa adanya peningkatan kemampuan pemahaman siswa terhadap teks bacaan berbahasa Inggris menerapkan context clues.
\end{abstract}

Kata kunci: pemahaman siswa, teks , context clues

\section{PENDAHULUAN}

Kemampuan memahami teks bacaan merupakan salah satu keahlian yang sebaiknya dimiliki siswa untuk menguasai materi teks yang diajarkan. Namun, pada kenyataanya, beberapa siswa belum merespon dengan baik kegiatan membaca dengan pemahaman ini. Hal ini disebabkan kurangnya media yang efektif dan metode yang efisien guna membantu siswa memahami teks bacaan. Misalnya, siswa tidak diberikan media pengajaran yang menarik sekaligus juga tidak diterapkan metode pembelajaran yang tepat yang mendukung sehingga siswa tidak tertarik untuk terlibat dalam mempelajari bahasa Inggris termasuk membaca dengan pemahaman ini. Padahal membaca dengan pemahaman merupakan faktor penting yang menentukan penguasaan siswa terhadap materi teks yang diajarkan (Juliana, 2018).

Selain itu, banyak siswa menghadapi beberapa kesulitan ketika mereka memahami teks bacaan. Walaupun mereka sudah membaca teks tersebut secara berulang-ulang. Beberapa kesulitan yang sering dihadapi siswa diantaranya adalah pertama, siswa tidak menguasai kosakata dan makna teks tersebut, kedua, siswa tidak mampu memahami maksud dan tujuan dari teks tersebut dan ketiga, siswa tidak mampu menentukan jenis teks yang dibaca. Oleh 
karena itu, diperlukan solusi yang efektif dan efisien untuk membantu siswa dalam memahami teks bacaan (Juliana, 2018).

Sebagai solusi meningkatkan kemampuan pemahaman siswa terhadap teks bacaan adalah dengan menyediakan metode pembelajaran yang efektif yang dapat membantu siswa memahami teks bacaan. Salah satu metode yang digunakan untuk membantu siswa memahami teks bacaan adalah metode membaca dengan menerapkan petunjuk konteks (context clues). Metode ini dapat digunakan untuk membantu siswa memahami teks bacaan dengan menerapkan beberapa tahapan metode yang memudahkan siswa dalam memahami teks bacaan (Emaliana, 2020).

Petunjuk konteks adalah petunjuk informasi dalam teks mengenai kosakata yang tidak diketahui artinya yang dapat digunakan dalam memahami dan menyimpulkan arti dari suatu kosakata dari teks bacaan. Petunjuk konteks dapat berupa kata-kata, gambar, grafik, tabel, dan catatan tambahan yang digunakan dalam teks bacaan.Ketika membaca sebuah kalimat dalam sebuah teks, siswa seringkali menemukan kata yang tidak diketahui artinya dan dianggap sebagai permasalahan dalam memahami sebuah teks (Humes, 1978). Sebagian siswa percaya bahwa tanpa mengetahui arti kosa kata mereka tidak dapat memahami maksud isi teks tersebut. Selain itu, siswa lainnya menganggap bahwa cara terbaik untuk menemukan makna kata-kata yang tidak diketahui adalah dengan menggunakan kamus. Namun apabila kamus yang diperlukan tidak tersedia, hal ini mengakitabkan siswa sulit menentukan arti dari kosa kata tersebut dan berdampak pada pemahaman terhadap terks bacaan. Oleh karena itu diperlukan solusi untuk membantu siswa memahami teks bacaan. Salah satu metode yang efektif guna membantu siswa memahami teks bacaan berbahasa Inggris adalah dengan menerapkan metode petunjuk konteks (Gill, S. R., \& Islam, 2011).

Menebak kosa kata dengan melihat dan menemukan petunjuk konteks adalah cara yang paling sering digunakan untuk membantu memahami maksud dari teks bacaan. Hal ini dapat dilakukan dengan cara menemukan arti kata yang tidak diketahui dengan mencari sejumlah petunjuk yang ada dalam teks bacaan(Juliana, 2020). Arti kata yang tidak diketahui tersebut sering dapat ditebak maknanya dengan menganalisis kalimat yang ada di sekitarnya. Hal ini dikarenakan penulis teks sering memberikan petunjuk dalam teks yang memungkinkan pembaca untuk memahami arti kata yang tidak dikenal dan diketahui tanpa harus mencari makna kata tersebut dalam kamus. Selain itu, ketika pembaca menggunakan petunjuk konteks mengenai kata yang tidak diketahui artinya, maka dalam hal ini pembaca dapat menemukan arti kata yang tidak diketahui dari kata-kata yang ada di sekitar teks baik berupa kalimat ataupun paragraf. Hal ini dapat membantu pembaca memahami arti dari kata yang tidak diketahui sekaligus membantu memahami teks bacaan (Carter, R. and McCarthy, 1988).

Menurut (McCullough, 1943), metode petunjuk konteks merupakan metode yang efektif dan efisien untuk menebak makna kata yang membantu memahami teks bacaan. Metode ini terdiri dari beberapa tahapan meliputi menebak makna kata dengan menemukan petunjuk konteks berupa sinonim, antonim, contoh dan penjelasan dari kata yang digunakan dalam teks. Pertama, petunjuk konteks sinonim adalah tahapan menebak makna kata dengan menemukan sinonim ataupun persamaan kata dalam teks bacaan. Hal ini membantu memahami teks bacaan dengan cara melihat persamaan kata yang berada sebelum atau sesudah kata tersebut. Kedua, petunjuk konteks antonim adalah tahapan menebak makna kata dengan menemukan antonym ataupun lawan kata dalam teks bacaan. Ketiga, petunjuk konteks contoh adalah tahapan menebak makna kata dengan menemukan contoh dalam teks bacaan. Keempat, petunjuk konteks penjelasan adalah tahapan menebak makna kata dengan menemukan explanation ataupun penjelasan dalam teks bacaan. (Jarkawi, 2019). Ringkasnya, metode petunjuk konteks sebagai solusi alternatif yang dapat digunakan untuk memudahkan siswa dalam memahami teks bacaan. Dengan kata lain, media pengajaran dan metode pembelajaran merupakan dua hal yang saling mendukung sebagai sarana bagi siswa untuk belajar bahasa Inggris dan sekaligus memahami informasi yang diajarkan (Rainey, E., \& Moje, 2012). 
Melalui kegiatan pengabdian kepada masyarakat yang bertema "Penerapan Metode Petunjuk Konteks Dalam Meningkatkan Kemampuan Pemahaman Bacaan Siswa" diharapkan dapat membuka wawasan, pemahaman dan kesadaran siswa akan pentingnya pembelajaran bahasa Inggris khususnya membaca dengan pemahaman sekaligus untuk meningkatkan motivasi dan kompetensi bahasa Inggris siswa. Dan untuk para guru, kegiatan berbagi informasi ini diharapkan dapat memberikan informasi yang berguna tentang media pengajaran dan metode pembelajaran bahasa Inggris.

Berdasarkan uraian latar belakang di atas, maka rumusan masalah pada kegiatan ini adalah:

1. Bagaimana media pengajaran dan metode pembelajaran yang digunakan untuk meningkatkan kemampuan pemahaman siswa terhadap teks bacaan berbahasa Inggris?

2. Bagaimana menerapkan metode petunjuk konteks untuk meningkatkan kemampuan pemahaman siswa?

Tujuan kegiatan Pengabdian kepada Masyarakat ini adalah :

1. Memperkenalkan media pengajaran dan metode pembelajaran dalam meningkatkan kemampuan pemahaman bacaan siswa

2. Meningkatkan kemampuan pemahaman bacaan siswa dengan penerapan metode petunjuk konteks.

\section{METODE}

Adapun tahapan Persiapan pelaksanaan Kegiatan Pengabdian kepada Masyarakat di SMA Harapan 3 Delitua adalah sebagai berikut:

1. Melakukan kajian studi pustaka tentang materi pengajaran dan pembelajaran membaca dengan memahami teks berbahasa Inggris

2. Melakukan persiapan bahan dan materi pendukung berupa materi penerapan metode petunjuk konteks sebagai metode pembelajaran yang dapat digunakan untuk meningkatkan pemahaman siswa.

3. Melakukan ujicoba materi yang disampaikan.

4. Menentukan waktu pelaksanaan dan lamanya kegiatan pengabdian bersama-sama tim pelaksana.

5. Menentukan dan mempersiapkan materi yang akan disampaikan dalam kegiatan pengabdian masyarakat.

Pelaksanaan kegiatan pengabdian berlangsung pada hari Sabtu, 26 Februari 2019 dari jam 08.00 sampai Selesai, dengan dihadiri 50 siswa kelas XI SMA Swasta Harapan 3 Delitua. Kegiatan pengabdian berlangsung diruang kelas SMA Swasta Harapan 3 Delitua.Kegiatan pengabdian diawali dengan penyampaian materi pokok kegiatan bertema pembelajaran dan penerapan metode petunjuk konteks dalam meningkatkan kemampuan pemahaman siswa. Kemudian, pemateri menjelaskan metode petunjuk konteks yang dapat diterapkan dalam meningkatkan pemahaman siswa. Kegiatan membaca dengan pemahaman terhadap teks berbahasa Inggris ini langsung dipraktekkan oleh siswa dengan mengarahkan siswa membaca teks yang diberikan dan menjawab beberapa persoalan terkait teks. Kemudian pemateri mengarahkan siswa untuk membaca dengan menerapkan metode petunjuk konteks. Dan pada akhir kegiatan, pemateri memberikan permainan berupa cara penerapan metode membaca petunjuk konteks. Siswa diarahkan untuk menentukan topic ataupun gagasanutama dalam teks dan menjawab persoalan terkait teks. Kegiatan pengabdian masyarakat ini dilakukan dalam bentuk seminar interaktif, yang meliputi kegiatan seperti presentasi,ceramah, diskusi, tanyajawab, game dan quiz yang terkait dengan topic pembelajaran bahasa Inggris terutama pembelajaran dan penerapan metode context clues dalam meningkatkan kemampuan 
pemahaman siswa. Berikut ini adalah Materi yang disampaikan kepada siswa SMA Harapan 3 Medan dalam bentuk kegiatan adalah sebagai berikut:

Tabel 1. Jadwal Acara Pelaksanaan Kegiatan Pengabdian Kepada Masyarakat SMA Harapan 3 Delitua

\begin{tabular}{|c|c|c|}
\hline Materi & BentukKegiatan & Capaian Materi \\
\hline $\begin{array}{l}\text { Melakukan Perkenalan } \\
\text { KepadaPeserta }\end{array}$ & Ceramah & Peserta Mengenal Pemateri \\
\hline $\begin{array}{l}\text { Menjelaskan Metode } \\
\text { memahami teks bacaan }\end{array}$ & Ceramah & $\begin{array}{l}\text { Peserta Mengetahui metode memahami teks } \\
\text { bacaan }\end{array}$ \\
\hline $\begin{array}{l}\text { Menjelaskan dan } \\
\text { Memberikan contoh } \\
\text { penerapan metode } \\
\text { memahami teks bacaan }\end{array}$ & $\begin{array}{l}\text { Ceramah, Latihan } \\
\text { dan Diskusi }\end{array}$ & $\begin{array}{l}\text { Peserta Mengetahui cara menerapkan } \\
\text { metode memahami teks bacaan. }\end{array}$ \\
\hline $\begin{array}{l}\text { Menjelaskan dan } \\
\text { menggunakan metode } \\
\text { context clues pada teks } \\
\text { bacaan }\end{array}$ & $\begin{array}{l}\text { Ceramah, Latihan } \\
\text { dan Diskusi }\end{array}$ & $\begin{array}{l}\text { PesertaMengetahuidanMenggunakanmetode } \\
\text { context clues pada teks bacaan }\end{array}$ \\
\hline $\begin{array}{l}\text { Soal } r \text { Latihan } \\
\text { pemahaman teks } \\
\text { bacaan menerapkan } \\
\text { metode context clues }\end{array}$ & $\begin{array}{l}\text { Ceramah, Latihan } \\
\text { dan Diskusi }\end{array}$ & $\begin{array}{l}\text { Peserta dapat menerapkan metode context } \\
\text { clues dalam memahami teks bacaan. }\end{array}$ \\
\hline $\begin{array}{l}\text { Menjawab soal latihan } \\
\text { terkait pemahaman } \\
\text { teks } \\
\text { menggunakan metode } \\
\text { context clues }\end{array}$ & $\begin{array}{l}\text { Ceramah, Latihan } \\
\text { dan Diskusi }\end{array}$ & $\begin{array}{l}\text { Pesertamenjawab dan Menyelesaikan } \\
\text { latihan soal terkait pemahaman teks bacaan } \\
\text { menggunakan metode conetxt clues. }\end{array}$ \\
\hline $\begin{array}{l}\text { Soal Latihan terkait } \\
\text { pemahaman terhadap } \\
\text { teks bacaan }\end{array}$ & $\begin{array}{l}\text { Ceramah, Praktek } \\
\text { dan Diskusi }\end{array}$ & $\begin{array}{l}\text { Peserta dapat menyelesaikan soal terkait } \\
\text { pemahan terhadap teks bacaan. }\end{array}$ \\
\hline Penutup & Ceramah & $\begin{array}{l}\text { Pesertadapat Menerapkan metode context } \\
\text { clues dalam memahami teks bacaan dan } \\
\text { membantu dalam menyelesaikan latihan } \\
\text { terkait pemahamn teks bacaan. }\end{array}$ \\
\hline
\end{tabular}

Tahapan prosedur pelaksanaan kegiatan pengabdian masyarakat di SMA Harapan 3 Delitua adalah sebagai berikut:

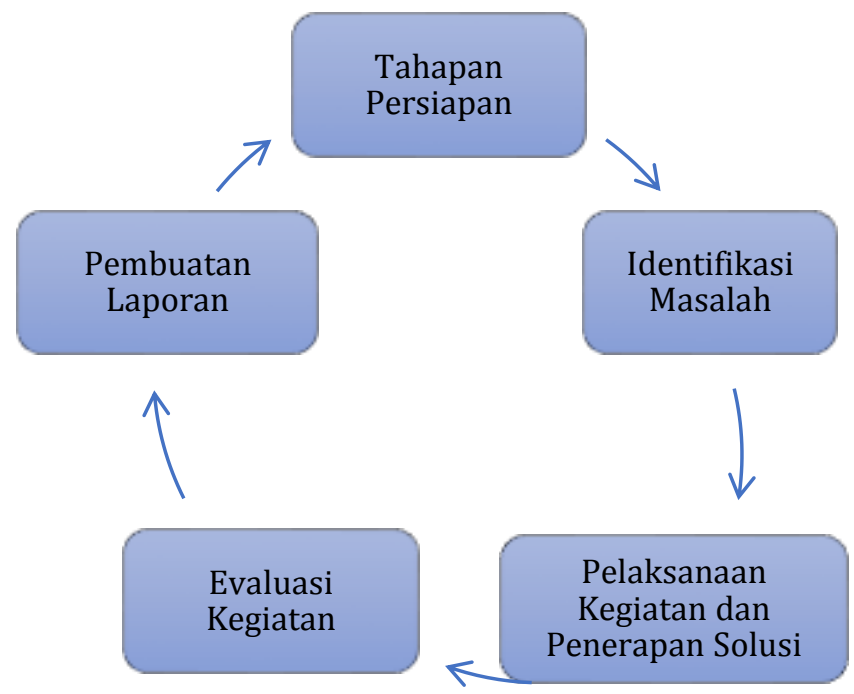

Gambar 1. Prosedur Pelaksanaan Kegiatan Pengabdian Masyarakat 
Pada gambar 1 menunjukkan prosedur Pelaksanaan Kegiatan Pengabdian Masyarakat di SMA Harapan 3 Delitua yang berlangsung dalam beberapa tahapan yaitu Tujuan kegiatan, Identifikasi masalah, Pelaksanaan dan penerapan solusi, Evaluasi kegiatan, dan Pembuatan Laporan. Adapun kegiatan yang dilakukan pada tiap-tiap tahapan adalah sebagai berikut:

a. Tahapan persiapan berupa penentuan dan survei lokasi Pelaksanaan Kegiatan pengabdian masyarakat.

b. Tahapan identifikasi masalah berupa Sosialisasi dan identifikasi permasalahan pada Lokasi pelaksanaan kegiatan Pengabdian masyarakat.

c. Tahapan pelaksanaan kegiatan berupa penerapan solusi terhadap permasalahan yang terjadi pada siswa SMA Harapan 3 Delitua berupa peningkatan kemampuan pemahaman siswa menggunakan metode context clues.

d. Evaluasi kegiatan dengan memberikan solusi terhadap kendala dan permasalahan setelah proses kegiatan selesai agar kegiatan dapat berlangsung dengan baik sesuai yang diharapkan.

e. Pembuatan Laporan Hasil kegiatan berupa Penyusunan laporan yang dikembangkan dengan cara menyajikan hasil studi pustaka, hasil pengumpulan data, hasil analisis data, dan kesimpulan yang diperoleh menyesuaikan dengan tujuan kegiatan pengabdian masyarakat.

\section{HASIL DAN PEMBAHASAN}

Beberapa jenis petunjuk konteks yang dapat membantu siswa memahami teks bacaan adalah sebagai berikut (Mahmoud, 2015)(Ahmad, S. N., Muhammad, A. M., \& Kasim, 2018):

\section{Penerapan Petunjuk Konteks Sinonim (Synonym)}

Petunjuk konteks sinonim (synonym clue) adalah petunjuk konteks yang digunakan untuk menebak makna kata yang tidak diketahui artinya dengan cara menemukan sinonim ataupun persamaan kata dalam teks bacaan (Warman et al., 2020). Hal ini membantu memahami teks bacaan dengan melihat persamaan kata yang berada sebelum atau sesudah kata tersebut. Didalam teks bacaan petunjuk konteks berupa sinonim ini dapat ditandai dengan penggunaan kata-kata yang ada sebelum atau sesudah kata yang tidak diketahui artinya. Contohnya:

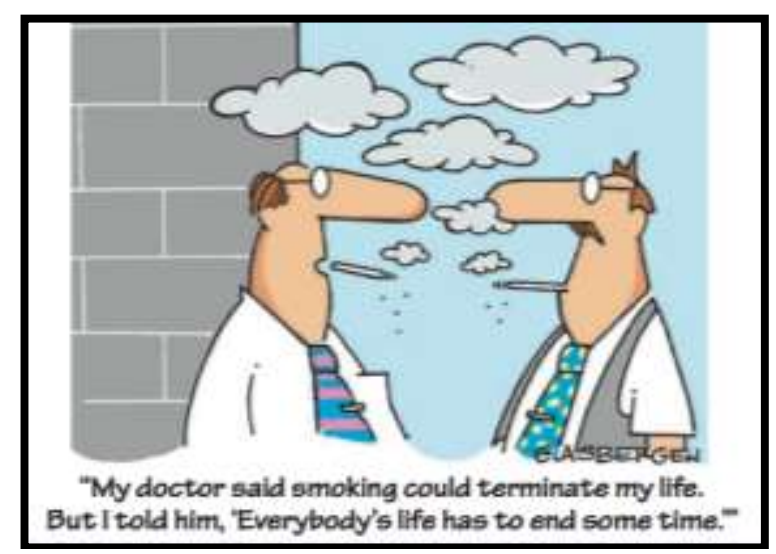

Gambar 2. Petunjuk Konteks Sinonim (Synonym)

Dalam gambar 2 terdapat pernyataan my doctor said smoking could terminate my life. But I told him, "Every body life has to end some time menggunakan kata atau frasa yang memiliki arti yang mirip dengan kata yang tidak diketahui. Kata "terminate" memiliki arti yang sama dengan kata "end". Contoh lainnya, dalam kalimat as soon as I made a flippant remark to my boss, I regretted sounding so disrespectful. Dalam hal ini kata flippant berarti hal sepele yang memiliki arti yang sama dengan kata disrespecful yang berarti hal biasa". Berikut ini gambar yang 
menunjukkan pengajaran pemahaman teks bacaan dengan mengunakan petunjuk konteks sinonim:

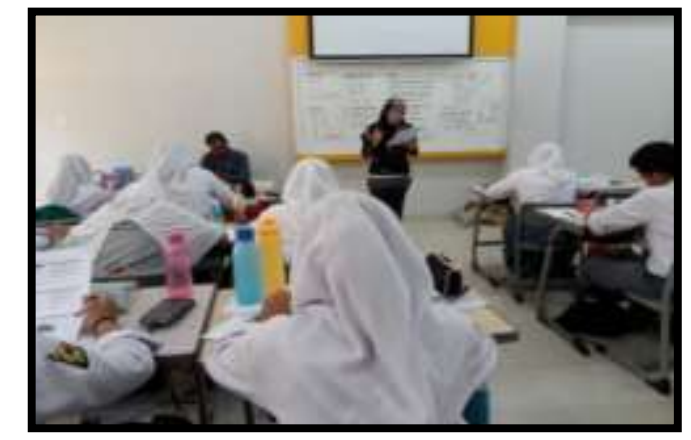

Gambar 3. Pengajaran Petunjuk Konteks Sinonim

Penerapan Petunjuk Konteks Antonim (Antonym)

Petunjuk konteks antonim (antonym clue) adalah petunjuk konteks yang digunakan untuk menebak makna kata yang tidak diketahui artinya dengan cara menemukan lawan kata ataupun antonim dalam teks bacaan. Dalam hal ini menggunakan kata atau frasa lain yang berarti kebalikan dari kata yang tidak dikenal. Kata-kata yang menandai antonim adalah "however, but, yet, on the other hand, instead of, and in contrast yang berarti "namun, tetapi, sebaliknya, tidak seperti, bukan". Contohnya:

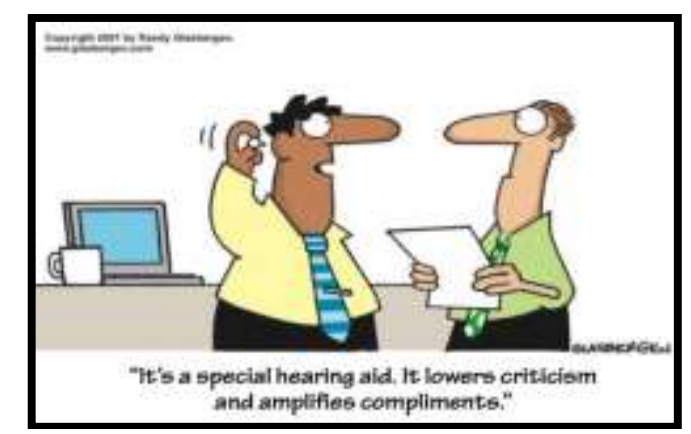

Gambar 4. Petunjuk Konteks Antonim (Antonym)

Dalam gambar ini terdapat pernyataan it's a special hearing aid. It lowers criticism and amplifies compliance menggunakan kata atau frasa yang memiliki arti yang berlawanan dengan kata yang tidak diketahui. Kata "lowers" memiliki arti menurunkan yang berlawanan dengan kata "amplifies" menaikkan. Contoh lain, dalam kalimat many people have pointed out the harmful effects that a working mother may have on the family, yet there are many salutary effects as well. Kata "harmful" memiliki arti berbahaya yang berlawanan dengan kata "salutary" bermanfaat (Aprizawati, 2020). Berikut ini gambar yang menunjukkan pengajaran pemahaman teks bacaan dengan mengunakan petunjuk konteks antonim:

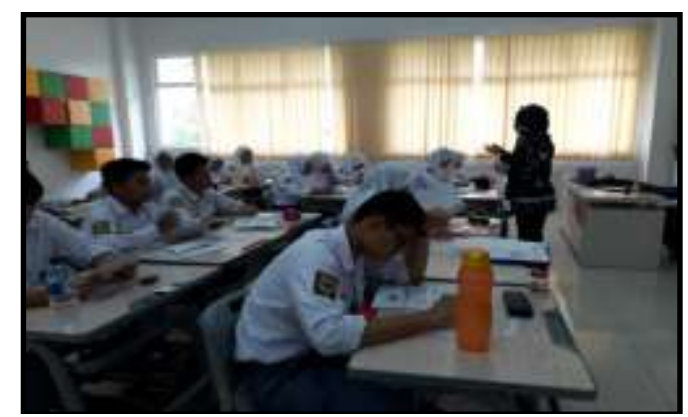

Gambar 5. Pengajaran Petunjuk Konteks Antonim 
Penerapan Petunjuk Konteks Contoh (Example)

Petunjuk konteks berupa contoh (example clue) adalah petunjuk konteks yang digunakan untuk menebak makna kata yang tidak diketahui artinya dengan cara menemukan contoh dalam teks bacaan. Didalam teks bacaan petunjuk konteks berupa contoh ini dapat ditandai dengan penggunaan kata-kata seperti for example, for instance, including, and such as. Contohnya,

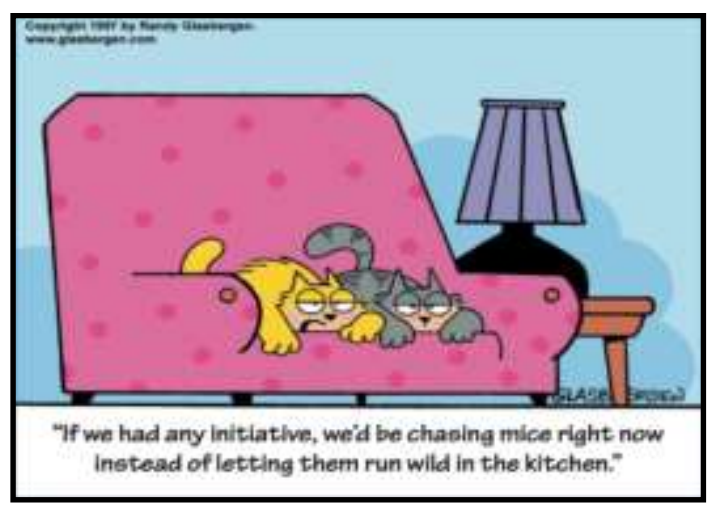

Gambar 6. Petunjuk Konteks Contoh (Example)

Dalam gambar ini terdapat pernyataan if we has any initiative, we'd be chasing mice right now instead of letting them run wild in the kitchen menggunakan kata atau frasa yang memiliki contoh kata yang tidak diketahui artinya. Kata iniciative memiliki arti yang mengandung contoh membiarkan tikus bebas" ini merupakan salah satu contoh bahwa tidak adanya niat ataupun tindakan inisiatif kucing yang dilakukan untuk menangkap tikus (Muzdaliifah, 2019). Contoh cats' having initiative-chasing mice-membantu memahami bahwa initiative berarti "ability to take charge."Contoh lainnya dalam kalimat, the adverse effects of this drug, including dizziness, nausea, and headaches, have caused it to be withdrawn from the market. Contoh dampak dari obat-obatan adalah pening, sakit kepala dan pusing. Contoh lainnya dalam kalimat mundane activities such as doing the laundry or dishes or going food shopping or reading the newspaper all help me relax. Contoh kegiatan diwaktu senggang adalah mencuci baju, piring, berbelanja dan membaca koran. Berikut ini gambar yang menunjukkan pengajaran pemahaman teks bacaan dengan mengunakan petunjuk konteks contoh:

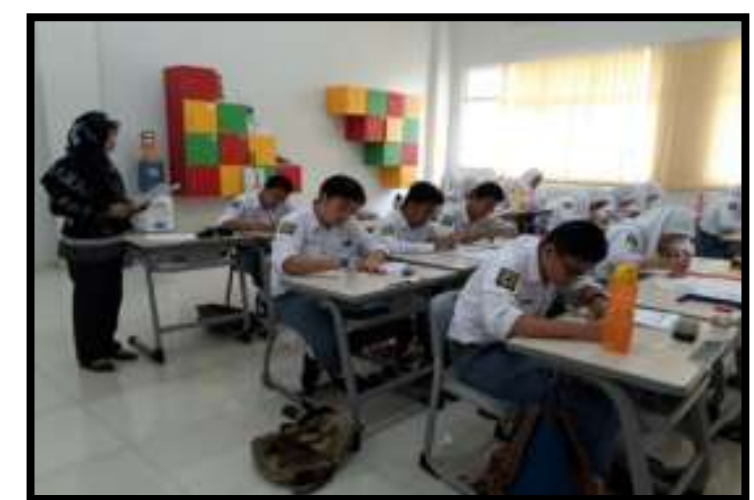

Gambar 7. Pengajaran Petunjuk Konteks Contoh

Penerapan Petunjuk Konteks Penjelasan Umum (General Sense)

Petunjuk konteks penjelasan umum (general sense clue) adalah petunjuk konteks yang digunakan untuk menebak makna kata yang tidak diketahui artinya dengan cara menyimpulkan maksud dalam teks bacaan. Contohnya, 


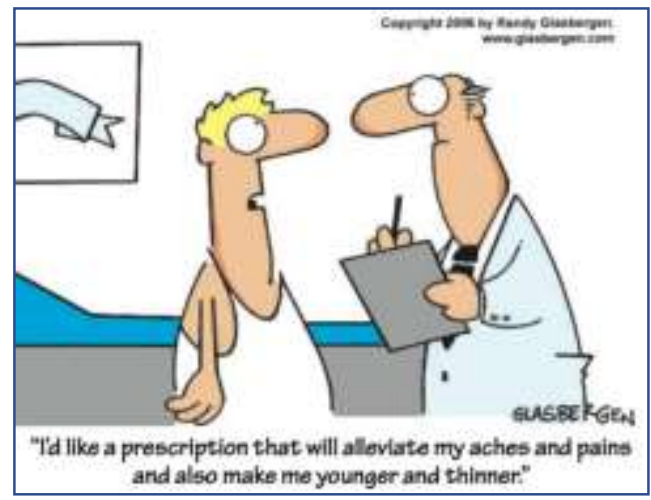

Gambar 8. Petunjuk Konteks Penjelasan Umum (General Sense)

Dalam gambar ini terdapat pernyataan I'd like a prescription that will alleviate my aches and pains and also make me younger and thinner yang berarti bahwa dokter akan memberikan resep untuk meringankan atau memulihkan sakit dilengan pasien. Kata alleviate berarti meringankan (Hamid, 2019). Contoh pernyataan lainya adalah The car wash we organized to raise funds was a fiasco-it rained all day. Hal ini berarti bahwa fiasco merupakan mencuci mobil setiap hari karena turun hujan berarti adanya salah satu bencana alam yang ditandai adanya hujan sepanjang hari mengakibatkan harus mencuci mobil. Berikut ini gambar yang menunjukkan proses pengajaran pemahaman teks bacan mengunakan petunjuk konteks penjelasan umum dan siswa mengerjakan soal latihan pemahaman teks bacaan berbahasa inggris menggunakan petunjuk konteks:

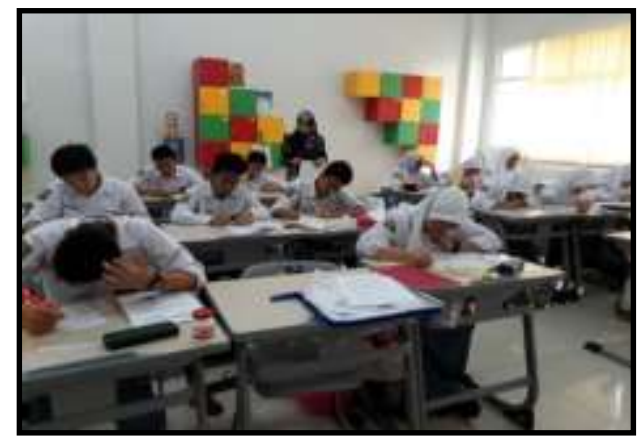

Gambar 9. Pengajaran Petunjuk Konteks Penjelasan Umum

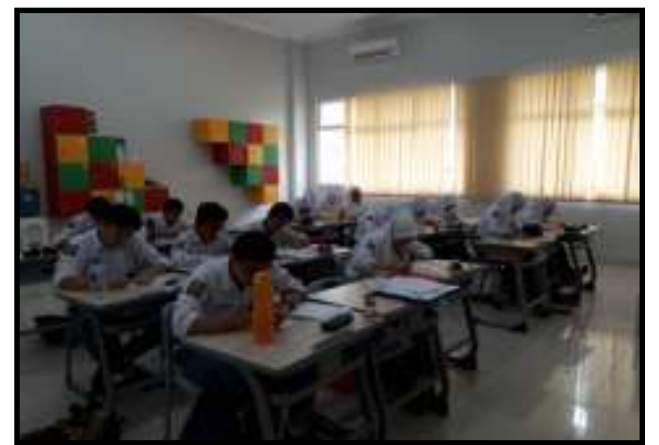

Gambar 10. Siswa Mengerjakan Latihan Pemahaman Teks Bacaan Petunjuk Konteks

Berdasarkan wawancara, Tanya jawab dan pengamatan langsung selama kegiatan berlangsung, kegiatan pengabdian pada masyarakat ini memberikan hasil sebagai berikut:

a. Meningkatnya pengetahuan dan pemahaman siswa kelas XI SMA Swasta Harapan 3 Delitua dengan menerapkan metode petunjuk konteks dalam memahami teks bacaan berbahasa Inggris. 
b. Meningkatnya kemampuan siswa kelas X SMA Swasta Harapan 3 Delitua dalam memahami teks bacan menggunakan metode petunjuk konteks pada pembelajaran membaca teks berbahasa Inggris.

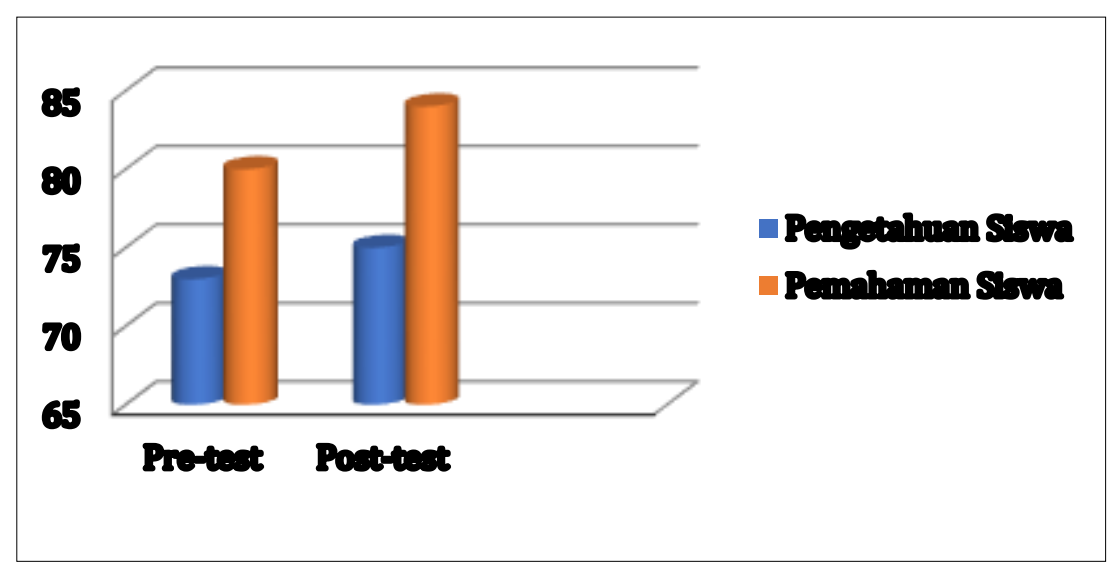

Gambar 11. Skor Pengetahuan dan Pemahaman Siswa terhadap Teks Bacaan

Gambar 11 menunjukan Skor pengetahuan dan pemahaman siswa terhadap metode pembelajaran dan penerapan petunjuk konteks. Skor pengetahuan siswa sebelum diajarkan petunjuk konteks pada pre-test diperoleh rata rata 73 dan skor pengetahuan siswa pada posttest meningkat setelah diajarkan metode petunjuk konteks menjadi 80. Skor pemahaman siswa terhadap teks bacaan berbahasa Inggris pada pre-test diperoleh rata-rata 75 dan skor pemahaman siswa pada post-test setelah menerapkan metode petunjuk konteks mengalami peningkatan menjadi 84. Hal ini menunjukkan bahwa adanya peningkatkan pengetahuan siswa terhadap metode pembelajaran petunjuk konteks dan pemahaman siswa terhadap teks bacaan berbahasa Inggris menerapkan metode petunjuk konteks (Ahmad, S. N., Muhammad, A. M., \& Kasim, 2018).

Selain itu, beberapa faktor yang mendukung terlaksananya kegiatan pengabdian kepada masyarakat ini adalah pihak Sekolah SMA Swasta Harapan 3 Delitua mendukung terlaksananya kegiatan pemateri, serta besarnya minat dan antusias peserta selama kegiatan, sehingga kegiatan berlangsung dengan lancer dan efektif. Sedangkan factor penghambatnya adalah keterbatasan waktu pelatihan.

\section{KESIMPULAN}

Dari kegiatan pengabdian kepada masyarakat ini dapat disimpulkan bahwa:

a. Adanya peningkatan pengetahuan dan pemahaman siswa kelas XI SMA Swasta Harapan 3 Delitua tentang pembelajaran dan penerapan metodepetunjuk konteks (context clues) dalam meningkatkan kemampuan pemahaman siswa terhadap teks bacaan berbahasa Inggris

b. Adanya Pengalaman baru bagi Siswa kelas XI SMA Swasta Harapan 3 Delitua tentang pembelajaran dan penerapan metode petunjuk konteks (context clues) dalam meningkatkan kemampuan pemahaman siswa terhadap teks bacaan berbahasa Inggris.

c. Mengingat besarnya manfaat kegiatan pengabdian kepada masyarakat ini, maka selanjutnya perlu bagi Para siswa yang telah diajarkan media dan metode pembelajaran petunjuk konteks (context clues) dapat menerapkan metode tersebut dalam kegiatan pembelajaran bahasa Inggris khususnya pemahaman terhadap teks bacaan.

d. Mengadakan pelatihan yang sama terhadap materi bahasa Inggris yang berbeda dengan khalayak sasaran yang lebih banyak. 
e. Mengadakan pelatihan tentang media pengajaran dan metode pembelajaran bahasa Inggris yang efektif dan efisien untuk guru bahasa Inggris.

\section{UCAPAN TERIMA KASIH}

Penulis mengucapkan terimakasih kepada Pihak LPPM Universitas Potensi Utama yang telah mendanai kegiatan pengabdian masyarakat ini. Selain itu penulis juga mengucapkan terimakasih kepada pihak Sekolah dan siswa SMA Harapan 3 Delitua, yang telah memberikan ijin dan berpartisipasi dalam menyukseskan kegiatan pengabdian masyarakat ini.

\section{DAFTAR PUSTAKA}

Ahmad, S. N., Muhammad, A. M., \& Kasim, A. M. (2018). Contextual Clues Vocabulary Strategies Choice among Business Management Students. English Language Teaching, 11(4), 107-116.

Aprizawati. (2020). Pelatihan Dan Bimbingan Smcp Terhadap Kemampuan Bahasa Inggris Maritim Calon Pelaut Di Kecamatan Bengkalis. Dinamisia: Jurnal Pengabdian Kepada Masyarakat, 3(2), 291-298. https://doi.org/10.31849/dinamisia.v3i2.3381

Carter, R. and McCarthy, M. (1988). Vocabulary and Language Teaching. Longman.

Emaliana, I. (2020). Pelatihan Penulisan Karya Ilmiah bagi Guru MGMP Bahasa Inggris SMA/MA se-Malang Raya. Dinamisia: Jurnal Pengabdian Kepada Masyarakat, 3(2), 273-279. https://doi.org/10.31849/dinamisia.v3i2.3380

Gill, S. R., \& Islam, C. (2011). Shared reading goes high-tech. The Reading Teacher, 65(3), 224227.

Hamid, S. andriyani. (2019). Pendampingan Guru Paud Ari-Ari Jepara Dalam Meningkatkan Pembelajaran Aud Berbasis Budaya. Dinamisia: Jurnal Pengabdian Kepada Masyarakat, 3(1), 124-130. https://doi.org/10.31849/dinamisia.v3i1.2812

Humes, A. (1978). Structures, signals, and cognitive processes in context clues. Research in the Teaching of English, 12(4), 321-334.

Jarkawi, J. (2019). Pelatihan Strategi Menganalisis Masalah Siswa Dengan Psiko-Edukasi Pada Smk Di Kabupaten Banjar. Dinamisia : Jurnal Pengabdian Kepada Masyarakat, 3(2), 313318. https://doi.org/10.31849/dinamisia.v3i2.3619

Juliana, J. (2018a). The Comparative Impacts of Using Lexical Glossing and Inferencing Strategies on Students' Reading Comprehension. Advances in Language and Literary Studies, 9(1), 1-5. https://doi.org/http://dx.doi.org/10.7575/aiac.alls.v.9n.1p.1

Juliana, J. (2018b). The Effect of Lexical Inferencing Strategies on Students' Reading Comprehension. Journal MELT (Medium for English Language Teaching),1(2), 126-143.

Juliana, Juliana. (2020). Peningkatan Motivasi Percakapan Bahasa Inggris Siswa Smk Wirakarya Mandiri Dengan Metode Dubbing Dan Subtitling. Martabe: Jurnal Pengabdian Kepada Masyarakat, 3(1), 81-88. https://doi.org/10.31604/JPM.V3I1.81-88

Mahmoud, S. S. (2015). How contextual clues and nonsense words facilitate reading comprehension. Journal of Language Teaching and Research, 7(1), 88-98.

McCullough, C. M. (1943). Learning to use context clues. The Elementary English Review, 20(4), 140-143., 20(4), 140-143.

Muzdaliifah, I. (2019). Sosialisasi Penggunaan Media Pembelajaran Scrabble Online Berbasis Android Untuk Guru- Guru Bahasa Inggris Sd It Al Birru Pekanbaru.Dinamisia: Jurnal $\begin{array}{llll}\text { Pengabdian Kepada } \quad \text { Masyarakat, } & \text { 3(1), }\end{array}$ https://doi.org/10.31849/dinamisia.v3i1.2197

Rainey, E., \& Moje, E. B. (2012). Building insider knowledge: Teaching students to read, write, and think within ELA and across the disciplines. English Education, 45(1), 71-90.

Warman, J. S., Mardian, V., Suryani, L., Fista, F. R., \& Irwan, I. (2020). Program Pelatihan Penigkatan Kemampuan Bahasa Inggris Anak-Anak Panti Asuhan Melalui Pemberdayaan Mahasiswa. Dinamisia: Jurnal Pengabdian Kepada Masyarakat, 3(2), 280-285. https://doi.org/10.31849/dinamisia.v3i2.3304 